УДК 1:316 (512.31)

DOI: $10.18101 / 1994-0866-2019-1-67-73$

\title{
МЕЖСОЦИУМНЫЕ ВЗАИМОДЕЙСТВИЯ В ИСТОРИИ БУРЯТСКОГО НАРОДА
}

\author{
(С) Рандалова Оюна Юрьевна \\ кандидат философских наук, доцент, \\ Бурятский государственный университет \\ Россия, 670000, г. Улан-Удэ, ул. Смолина, 24а \\ E-mail: oyuna.randalova@gmail.com
}

В работе рассматривается проблема методологии исследования взаимодействия социумов, находящихся на разных стадиях социального развития. Межсоциумные взаимодействия - это взаимодействия отдельных обществ, взятых в их целостности. В таком понимании есть взаимодействия «по горизонтали», как связи между сосуществующими в пространстве социальными организмами, связи синхронные. Методология общественного синтеза органично сочетается со всеми тремя основными направлениями современного обществоведения: формационный (межформационный синтез), цивилизационный (межцивилизационный синтез) подходы, не будет противоречивой идея синтеза и мир-системному анализу (отношения «ядро» «периферия» применительно к экзогенному синтезу). Предложенный подход синтеза общественных форм раскрывается на примере истории бурятского народа. Бурятский социум представляется как результат исторического синтеза различных общественных отношений. В данной работе явления синтеза рассматриваются на примере социально-экономической сферы бурятского социума как типичного представителя сибирских этносоциумов.

Ключевые слова: межсоциумные взаимодействия; синтез общественных форм; евразийский синтез; социум; Россия; патриархально-родовые отношения; капитализм; бурятский народ.

\section{Для цитирования:}

Рандалова О. Ю. Межсоциумные взаимодействия в истории бурятского народа // Вестник Бурятского государственного университета. Философия. 2019. Вып. 1. C. $67-73$.

Понятие «межсоциумные взаимодействия» определяется нами как взаимодействия между социумами, то есть конкретными отдельными обществами. При этом социум представляет собой единство стадиального типа и этнической общности. В методологии отечественного исследователя Ю. И. Семенова это социально-исторический организм. У него же такие взаимодействия получили название «межсоциорные». Следует подчеркнуть, что речь идет о взаимодействиях в основном между обществами, находящимися на разных стадиях развития. Вместе с тем такое понимание не исключает возможности рассмотрения цивилизационной принадлежности социума. Межсоциумные взаимодействия - это взаимодействия отдельных обществ, взятых в их целостности. В таком понимании есть взаимодействия «по горизонтали», как связи между сосуществующими в пространстве социальными организмами, связи синхронные. Именно отсутствие внимания к такого рода взаимодействиям было упреком марксистской теории исторического процесса. Так, например, в работе В. В. Ильина «Философия истории» это является существенным аргументом в пользу элиминации формаци- 
онного подхода из социальной теории вообще [1]. Ортодоксальный вариант теории общественно-экономических формаций концентрирует внимание только на связях во времени, диахронных, понимаемых крайне односторонне, лишь как связи между различными стадиями развития внутри одних и тех же социальных организмов.

В теории общественно-экономических формаций о межсоциумных взаимодействиях более явственно заговорили в связи с необходимостью обосновать некапиталистический путь развития, когда общества, не прошедшие стадию капитализма, могли миновать ее, сразу перейдя на более высокую стадию развития. В качестве основания ссылались на «Наброски ответа на письмо Веры Засулич» К. Маркса, в которых он очень осторожно предполагал такую возможность, имея в виду общинную организацию российской действительности того времени [2]. В работе «Теоретические проблемы всемирно-исторического процесса» авторы, типологизируя формы переходных отношений, выделяли «общества, которые перешли в орбиту новой формации в силу исторической неодолимости новой формации или /что то же/ под воздействием закона исторической корреляции, с неизбежностью сказывающейся между народами, составляющими определенную международную систему. Для стран «запоздавших» этот закон вступает в силу лишь тогда, когда новая формация достаточно хорошо укрепилась» [3].

Переход общества на более высокую ступень развития под воздействием только внутренних противоречий происходил во всемирной истории не очень часто. Большую роль в осуществлении поступательного движения человечества «к своей подлинной всемирной истории» играют отношения исторической корреляции социумов. «Суть подобных отношений, - отмечал К. Х. Момджян, проявляется в целенаправленном или спонтанном подтягивании» лидерами аутсайдеров путем «экспорта» новых форм общественной организации, благодаря чему последние пытаются миновать «естественные» в плане внутренней логики фазы своего развития [4]. В исторической литературе наиболее распространенным является определение данного способа перехода на более высокую ступень развития как способа формационного синтеза, экстраполирующее идею «феодального синтеза» на процесс возникновения и других формационных типов. Общество, которое на данный момент взаимодействия обладает большим потенциалом, вынуждает второе общество меняться. В теории общественноэкономических формаций это изменение во многом рассматривалось как позитивное, прогрессивное. Под общественно-историческим синтезом понимается процесс взаимодействия каких-либо разнородных социально-экономических или политико-идеологических начал, когда происходит переплетение, слияние, образование некой внутренне противоречивой целостности. Синтез представляет собой данный процесс и его конкретные результаты. Общественный синтез может возникать как в ходе естественного саморазвития общества (эндогенный синтез), так и в результате воздействия на общество извне. В том или ином виде общественный синтез присутствует или присутствовал в любом процессе исторического развития [5]. Это прежде всего формационный синтез, именно в рамках формационной теории развивалась идея общественного синтеза. Методология общественного синтеза органично сочетается со всеми тремя основными направлениями современного обществоведения: формационный (межформационный синтез), цивилизационный (межцивилизационный синтез) подходы, не будет 
противоречивой идея синтеза и мир-системному анализу (отношения «ядро» «периферия» применительно к экзогенному синтезу).

Историческое развитие народов Сибири показывает уникальный опыт социального синтеза общественных отношений. Речь идет о длительном взаимодействии России и Бурятии, Якутии, Хакасии, Горного Алтая, Тувы и других этнических территорий.

Составные части России находились в пределах единого территориального пространства, что во многом предопределило своеобразие рассматриваемого прецедента. Со времени завоевания Сибири российским государством здесь постепенно, столетиями формировалась единая общественная система, объединяющая различные в своем реальном существовании отдельные организмы, социумы, какими являются бурятский, якутский, тувинский и другие народы. В этом плане прав Ю. И. Семенов, утверждая, что дореволюционная Россия не являлась единым социальным организмом: «Россия представляла к моменту революции сложную систему социальных организмов и их федераций, ядром которой был великорусский социальный организм» [6]. Взаимодействие со своей метрополией этих социумов, находящихся на разных уровнях стадиального развития, можно рассматривать в разных аспектах: экономическом, политическом, культурном, цивилизационном. Межсоциумные взаимодействия в евразийском пространстве - это и межэтнические, и кросскультурные взаимодействия, но немаловажным фактором является и разноуровневость исторического развития. Рассмотрение межсоциумных взаимодействий в евразийском регионе с использованием идеи общественно-исторического синтеза, по нашему мнению, позволит дополнить как саму методологию общественного синтеза новым локальным вариантом исследования, так и внести новый элемент в философско-исторический анализ развития данного региона. Понятие «евразийство» имеет двоякое значение. Во-первых, евразийство как социально-теоретический концепт, во-вторых, как реальный исторический процесс взаимодействия социумов, результирующий в особую субкультуру, субцивилизацию в пространственной определенности. Именно в данном, втором, значении понятие «евразийский» мы используем в нашей работе. Межсоциумные взаимодействия включают такие процессы, как восприятие и освоение народами азиатской России элементов европейской, русской культуры. Народы Центральной и Северной Азии не только являлись реципиентами достижений русской европейской цивилизации, но и отстаивали и обогащали свое автохтонное цивилизационное наследие. В течение всего 20-го столетия, особенно в советскую эпоху, здесь шел многоуровневый исторический процесс взаимодействий, взаимовлияний русской, европейской цивилизации и цивилизаций тюркоязычного и монголоязычного миров, представленных бурятским, якутским, тувинским, алтайским и другими народами. Но и к началу советского периода, к примеру, бурятский социум уже представлял собой результат общественно-исторического синтеза различных общественных отношений. В данной работе явления синтеза рассматриваются на примере социальноэкономической сферы бурятского социума как типичного представителя сибирских этносоциумов.

В момент вхождения в состав Российской империи буряты были носителями кочевой культуры Восточной Сибири. В исследованиях по истории народов Сибири показывается, что в период присоединения к Российской империи народы Сибири находились на разных стадиях исторического развития — от поздних 
ступеней первобытно-общинной формации до зачатков феодальной системы. Относительно последнего тезиса о зачатках феодальных отношений существуют спорные мнения. Несомненным является факт складывания раннеклассового общества, социальной дифференциации, обособления элиты. Важным моментом представляется наличие сложившихся традиций данничества, института ясака. Что имело следствием «более щадящие, адаптивно гибкие и конструктивные формы взаимоотношений русских с аборигенами» [7]. Стадиальный (формационный, цивилизационный) разрыв между взаимодействующими социумами был не настолько катастрофичен, чтобы породить полную несовместимость хозяйственно-культурных укладов пришельцев и аборигенов, как это происходило, к примеру, на северо-востоке Евразии (взаимодействие чукотского и российского социумов было гораздо драматичнее) или на западе США, где произошло полное «очищение» территорий от коренного населения [7]. О некорректности, по нашему мнению, использования понятия «фронтир» применительно к межсоциумным отношениям уже отмечалось в других работах [8]. По мере углубления государственной колонизации и увеличения численности русского населения нарастали процессы взаимовлияния русского крестьянского и местного скотоводческого населения, распространения русской культуры, которая в исторической перспективе явилась транслятором европейской. Постепенно здесь в течение длительного периода формируется социально-экономический синтез: патриархально-родовой-полуфеодальный, но при этом в условиях верховной собственности государства, и о феодальных отношениях говорить сложно. Синтез в системе материального производства имел продолжение в системе социального уклада жизни: бурятский народ, исконный носитель восточной скотоводческой культуры, начинает переходить к западной, земледельческой культуре, цивилизации. Он становится носителем своеобразного русско-бурятского синтеза материальной и духовной культуры.

Россия в момент присоединения была феодальной, крепостнической, вся земля за Уралом считалась «государевой вотчиной» и принадлежала казне. Все земли сибирских народов были объявлены государственной собственностью, население обложено ясаком (данью), позднее ясак заменился феодальной рентой [9]. Вовлечение бурятского народа в общую систему налогообложения усилила социальную дифференциацию и положение высшего слоя - нойонов, которые стремились сосредоточить в своих руках основные ресурсы и усилить внеэкономическое принуждение. «...царская администрация старалась не разрушать сложившуюся внутреннюю организацию аборигенов, пытаясь опереться на нее, привлекая на свою сторону родоплеменную знать. Вскоре местные князья начали отвечать за сбор ясака, что было им очень выгодно, так как имелась возможность оставлять излишки при себе, особенно на первых порах, когда точного учета числа налогоплательщиков в острогах еще не было» [9]. Государственная политика Российской империи была гибкой, многообразной, учитывающей исторические особенности экономической и социальной структуры колонизируемых народов. Складывался синтез общественных отношений - патриархальнородовая-полуфеодальная система организации бурятского общества. Этот синтез социальной организации бурятского общества был характерен почти до конца XIX в. Таким образом, буряты избежали, как и крестьяне Сибири в целом, крайностей феодального режима метрополии - крепостничества, и этот же фактор в 
значительной мере обусловил сравнительно легкое переключение бурятского хозяйства на рельсы капиталистического развития.

Новый этап развития стадиального синтеза начинается на рубеже XIX$\mathrm{XX}$ вв. Дальнейшее развитие исторического взаимодействия приводило к накладыванию общественных форм, к их сращенной форме. Быстро развивающийся русский капитализм во второй половине XIX в. втягивал в водоворот своего развития окраины России, разрушая всюду докапиталистические отношения, патриархальную замкнутость, оказывая влияние на экономический и социальный строй народов, населяющих эти окраины. Хозяйство бурят, будучи не изолированным от хозяйства окружающих русских крестьян и вообще от условий общего капиталистического развития Сибири, испытало такое влияние в полной мере. Строительство Транссибирской железной дороги, рост золотодобывающей промышленности, а также подати, которые с давних пор отправлялись деньгами, оказывали сильное влияние на товаризацию местного производства, все больше и больше вовлекая бурятское население в товарно-денежные отношения. По данным И. А. Асалханова, происходил достаточно заметный процесс дифференциации бурятских крестьян на наймодателей и нанимающихся работников. Так, $70 \%$ хозяйств, имеющих минимальное число скота, не могло жить за счет своего хозяйства и было вынуждено продавать рабочую силу. Часть бедняков кроме найма в работники уходила из пределов ведомства «на отхожие заработки», батрачила у богатых русских крестьян и казаков. К «отхожим заработкам» относились работа на золотых приисках, плотницкая работа на строительстве пароходов, добыча и доставка угля. Немногочисленная часть крестьян наряду с применением наемного труда в своих хозяйствах прибегала к аренде сенокосных угодий для предпринимательства, занималась продажей значительного количества скота - от 30 до $50 \%$ всего поголовья, имевшегося в их стадах [10]. Кроме процесса расслоения в бурятских улусах шло также «обуржуазивание» нойонства. Нойоны, как отмечалось, не являлись феодальными земельными собственниками. Землевладение нойонов слагалось из захватных земель (пашен, утугов, а в Забайкалье - сенокосов), арендованных и отводных земельных угодий. Отсутствие феодального землевладения способствовало эволюции их хозяйства по капиталистическому пути, оно было втянуто в товарные отношения в большей степени, чем хозяйства зажиточных бурят. Среди нойонов было больше крупных предпринимателей, чем среди родовых улусных кулаков.

О большой социально-экономической дифференциации свидетельствуют данные, приводимые П. И. Малахиновым: в конце XIX в. 4,3\% хозяйств были безлошадными, $3,1 \%$ - без крупного рогатого скота и $24 \%$ - без овец [11]. Авторы современной «Истории Бурятии» справедливо отмечают: «Изменения в экономической и общественной жизни бурят, прежде всего, проявились в органичном включении их хозяйств в основные исторические процессы, характерные для начала XX в. в России. Ведущей и необратимой тенденцией исторического развития бурят стали противоречия, порождавшиеся ростом мелкотоварного и капиталистического производства. Капитализм все более подчинял себе другие общественно-экономические уклады» [12]. Тем не менее капиталистические отношения не могли развиться в достаточной степени в силу неразвитости этих отношений в самой метрополии. Новые стадиальные изменения в истории бурятского народа, других народов Сибири начались с Октябрьской революции. Следует отметить, что к этому моменту общественный строй бурят представлял со- 
бой синтез уже трех типов общественных отношений — родоплеменных, феодальных и капиталистических.

Таким образом, к приходу советской власти общественный строй бурят представлял собой синтез уже трех типов общественных отношений - родоплеменных, феодальных и капиталистических, при этом переплетались и синтезировались они не в своих чистых формах, а в неразвито-симбиозных, аморфных, «неартикулированных».

Крупной исторической вехой в истории этнического выживания и сохранения автохтонных цивилизационных традиций для бурятского народа в XX в. явился великий социальный переворот 1917 г. в стране, создание нового общественного строя, который предоставил единственную уникальную возможность для малых народов и наций в значительной степени отойти от колониального порабощения и сохранить, развить ценности своего генетического духовного бытия.

В новейшую эпоху, с середины XX в., вплотную соприкоснувшись с феноменом западной цивилизации, бурятский народ начал интенсивное и деятельное освоение русской, европейской культуры, всего духовного богатства европейской цивилизации. Это открыло перед народом путь к научно-техническому прогрессу, достояниям мировой техногенной цивилизации и духовной культуры.

Вместе с тем необходимо учитывать амбивалентность процесса синтеза в том смысле, что XX век был также веком разрушения самобытной кочевой цивилизации и культуры бурятского народа, которое началось еще с XVII в. - со времени включения сибирских этносов в состав Российской империи. В современную эпоху уже не представляется возможным говорить о бурятском народе как о представителе только восточной цивилизации во всех сферах жизнедеятельности. Скорее, это социум со сформировавшейся евразийской ментальностью, евразийской синтезированной культурой на прочном основании национальной идентичности.

Литература

1. Ильин В. В. Философия истории. М., 2003. С. 25.

2. Маркс К., Энгельс Ф. Соч. 2-е изд. Т. 19. С. 400-421.

3. Теоретические проблемы всемирно-исторического процесса / Е. М. Жуков [и др.]. М., 1979. С. 122.

4. Момджян К. Х. Социум. Общество. История. М.,1994. С. 131.

5. Непомнин О. Е, Меньшиков В. Б. Синтез в переходном обществе: Китай на грани эпох. М., 1999. С. 5-6.

6. Семенов Ю. И. Категория «социальный организм» и ее значение для исторической науки // Вопросы философии. 1966. № 8. С. 105.

7. Азиатская Россия в геополитической и цивилизационной динамике. XVIХХ вв. / В. В. Алексеев [и др.]. М., 2004. С. 565.

8. Рандалова О. Ю. Проблема теории фронтира в применении к истории Сибири // Социокультурные процессы в условиях интеграции и дизинтеграции общества. УланУдэ: Изд-во Бурят. гос. ун-та, 2017. С. 154-156.

9. Залкинд Е. М. Общественный строй бурят в XVIII - первой половине XIX в. М., 1970. C. 392.

10. Асалханов И. А. Социально-экономическое развитие Юго-Восточной Сибири во второй половине ХІХ века. Улан-Удэ, 1963. С. 278.

11. Малахинов П. И. О двух типах аграрной эволюции. Улан-Удэ, 1962. С. 350. 
12. История Бурятии: в 3 т. T. 2. XVII - начало XX в. Улан-Удэ: Изд-во БНЦ СО РАН, 2011. С. 237.

\section{INTERSOCIETAL INTERACTIONS IN THE HISTORY OF THE BURYAT PEOPLE}

Oyuna Yu. Randalova

Cand. Sci. (Philos.), A/Prof. of Philosophy Department, Buryat State University 24a Smolina St., Ulan-Ude 670000, Russia

E-mail: oyuna.randalova@gmail.com

The article deals with the problem of the methodology for studying the interaction of societies at different stages of social development. Intersocial interactions are interactions of individual societies in their integrity. In this understanding, inter-societal interactions are so-called "horizontal" interactions, relations between social organisms that coexist in space, or synchronous relations. The methodology of social synthesis is congruent with all three main fields of modern social science: formational (interformational synthesis), civilizational (intercivilizational synthesis) approaches, and world-system analysis (relations "core" - "periphery" with reference to exogenous synthesis). The proposed approach to the synthesis of social forms is revealed on the example of the history of the Buryat people. Buryat society is a result of the historical synthesis of various social relations. In the article, we consider the phenomena of synthesis through the example of the socio-economic sphere of Buryat society as a typical Siberian ethnic socium.

Keywords: intersocietal interactions; synthesis of social forms; Eurasian synthesis; society; patriarchal and tribal relations; capitalism; the Buryat people. 